\title{
Manfreda Sommera filozofia zbierania
}

\author{
Witold Nowak \\ https://orcid.org/0000-0002-3799-1851
}

Artykuł poświęcony jest filozofii Manfreda Sommera i jego fenomenologii praktyk zbierania. Podstawą koncepcji Sommera jest odróżnienie zbierania ekonomicznego i estetycznego. Zbieranie ekonomiczne ma charakter nierozróżniającej kumulacji. Zbieranie estetyczne jest różnicujące, nakierowane na indywidualne cechy przedmiotu. Przy bliższej analizie pierwsze okazuje się ułomną, niepełną odmianą drugiego. Zbieranie i kolekcjonowanie mają u swego źródła fakt, że człowiek to homo videns - istota, która znajduje najwyższą radość w oglądzie i która pragnie trwać w owym oglądzie na zawsze. Omówienie koncepcji Sommera kończy się zebraniem uwag wobec niej krytycznych.

Słowa kluczowe: zbieranie, kolekcjonowanie, rzecz, Manfred Sommer

Częściej niż jesteśmy gotowi to przyznać robimy coś, zaczynamy się jakoś zachowywać, zanim naszą czynność zaczniemy ujmować i kontynuować jako działanie intencjonalne. Cel wymyślamy wówczas, gdy już jesteśmy w drodze; zachowujemy się jednak potem tak, jakbyśmy dążyli do niego od samego początku. Nasze działanie, podobnie jak nasze zbieranie i nasze życie, ma często formę opóźnionego początku'.

WITOLD NOWAK, doktor habilitowany, prof. UR, Instytut Filozofii, Wydział SocjologicznoHistoryczny (Kolegium Humanistyczne), Uniwersytet Rzeszowski; adres do korespondencji: al. T. Rejtana 16 C, 35-959 Rzeszów; e-mail: nowwit@interia.pl

${ }^{1}$ Manfred Sommer, Zbieranie. Próba filozoficznego ujęcia, tłum. Jarosław Merecki (Warszawa: Oficyna Naukowa, 2003), 255. 


\section{Wstęp}

Praktyki zbierania i kolekcjonowania są dziś analizowane z perspektywy różnych dyscyplin badawczych. Naturalną koleją zajmują się nimi muzealnicy, historycy archiwów i dokumentaliści. Czynności te bada się także z perspektywy historii kolekcji. Istnieją również studia psychologiczne poświęcone kolekcjonerstwu, a psychologizowanie tego zjawiska jest chyba także dominantą świadomości potocznej. Filozofia bardzo długo pozostawiała kolekcje i praktyki zbierackie poza obrębem swych zainteresowań. Jeśli już poświęcała uwagę tym ostatnim, to na gruncie antropologii i poszukiwania czynności specyficznie ludzkich - tego, co stanowi humanum ${ }^{2}$. Filozoficzno-historyczne studia nad kolekcjami zainicjował na dobre polski badacz K. Pomian, autor klasycznej pracy Zbieracze i osobliwo$s c^{3}$. Kiedy rozpoczynał badania nad kolekcjami, był niemal sam, natomiast obecnie liczba badaczy kolekcji jest już stosunkowo duża ${ }^{4}$.

Niemiecki filozof Manfred Sommer (ur. 1945) - w latach 1974-1982 asystent Hansa Blumenberga, a później wydawca jego spuścizny, emerytowany profesor uniwersytetu w Kiel - zaprezentował wobec zbierania podejście stricte filozoficzne. Stosując filozoficzną metodę fenomenologiczną i wystrzegając się mocnych przedzałożeń, spróbował on poddać oglądowi i uważnemu opisowi realne praktyki zbierania w ludzkim świecie, w Lebenswelt. Sommer opisuje mianowicie, jak zbieracz integruje swoją wiedzę i wolę, postrzeganie i fantazję; oraz jak na

${ }^{2}$ Za pierwsze kolekcje uznawany jest zbiór kamyków z jaskini we Francji, pochodzący sprzed 80000 lat i nieco późniejsze akumulacje muszelek i kawałków pirytu odnalezione w grocie Hieny w Arcy-sur-Cure. Wtedy też musiało się narodzić kolekcjonerstwo pojęte jako gromadzenie przedmiotów nie dla ich celów użytkowych. Zob. The Cultures of Collecting, red. John Elsner, Roger Cardinal (Cambridge, Mass.: Harvard University Press, 1994), 2.

${ }^{3}$ Krzysztof Pomian, Zbieracze i osobliwości. Paryż-Wenecja. XVI-XVIII wiek, tłum. Andrzej Pieńkos (Gdańsk: Słowo/Obraz Terytoria, 2012).

${ }^{4}$ Pomian pokazywał ponadto związki kultury kolekcjonerskiej z badaniami naukowymi i filozofią nowożytnej Europy. Zob. Krzysztof Pomian, Kolekcjonerstwo i filozofia. Narodziny nowożytnego muzeum, w: Krzysztof Pomian, Drogi kultury europejskiej. Trzy studia (Warszawa: IFiS PAN, 1996), 113 i n. Z nowszych, w tym filozoficznych prac o kolekcjonowaniu zob. Lothar Beinke, Sammeln und Sammler (Tönningen: Der Andere Verlag, 2005); Philipp Blom, Sammelwunder, Sammelwahn. Szenen aus der Geschichte einer Leidenschaft (Frankfurt am Main: Eichborn, 2004); Philipp Blom, To Have and to Hold. An Intimate History of Collectors and Collecting (New York: Overlook Press, 2003); Andreas U. Sommer, Dagmar Winter, Miguel Skirl, Die Hortung. Eine Philosophie des Sammelns (Düsseldorf: Parerga Verlag, 2000). 
mocy owej integracji może wykonywać ruchy, za sprawą których to, co było „tam” rozproszone, gromadzi „tutaj”. Dodajmy, że stosowanie metody fenomenologicznej decyduje o pewnej kolistości, nawrotowości prezentowanych rozważań filozofa: sens zbierania ulega dzięki temu stopniowemu rozjaśnianiu. Metoda Sommera nie lekceważy też podejścia właściwego filozofii analitycznej i hermeneutyce; poświęca on uwagę odkrywanym w praktyce języka znaczeniom kluczowych słów, zwłaszcza zbierania, ale też kolekcjonowania, budowania, czytania. Uważne słuchanie mowy kieruje nas ku słowom, które od wielu setek lat nazywają interesujące nas praktyki zbierania, żegnania bliskich, przypominania sobie czegoś, liczenia. W słowach tych Sommer pokazuje nam zapoznane sensy, które rozświetlają znaczenie wykonywanych wciąż praktyk. W ten sposób w nowoczesnych praktykach rozpoznajemy pradawne rytuały powiązane z kultem, służące wzmacnianiu wspólnot albo przetrwaniu: „Rolnik jest bowiem przede wszystkim kimś, kto buduje (bauen) - uprawia (anbauen) i wznosi (aufbauen). Zajmuje się uprawą roli i budową domów"5 . Sommer nie przecenia jednak badań etymologicznych: etymologia nie jest dla niego środkiem poznania rzeczy, lecz daje do niego impuls albo je wieńczy.

\section{Wobec psychologii zbierania}

Najdalszy jest Sommer od psychologizowania czynności kolekcjonerskich. Nie stara się dociec owych ukrytych bodźców, które rzekomo motywują zbiera$\mathrm{czy}^{6}$. Odrzuca w tym kontekście pojęcie „popędu zbierania” jako terminu ostatecznego, który miałby wyjaśniać genezę czynności kolekcjonerskich. Owszem, powiada trafnie, popęd taki istnieje, jeśli tylko uważamy, że tak jest i jeśli stosujemy go do autoopisu naszych motywacji. Jednak: „Konstytucja i funkcja tego, co

${ }^{5}$ Sommer, Zbieranie, 364.

${ }^{6}$ Oczywiście rozmaite strategie perswazyjne stosuje się w reklamie, zwłaszcza skierowanej do dzieci, mającej na celu nakłonienie ich do zbierania różnego rodzaju zabawek i obiektów kolekcjonerskich. Producenci narzucają tu ludziom swoją wolę, wykorzystując wiedzę z obszaru psychologii społecznej, która mówi, jakimi sposobami utrzymywać dzieci i nie tylko w stanie ciągłego niezaspokojenia i pragnienia nabycia kolejnego obiektu z kolekcjonerskiej serii. Zob. Marcin Napiórkowski, „Co zbierają nasze dzieciaki”, Tygodnik Powszechny 2019, nr 31: 12-16. Zob. też Russell W. Belk, Collecting in a Consumer Society (London, New York: Routledge, 2001). 
odczuwamy jako popęd zbierania, mogą zostać ujęte tylko przez obserwację naszych czynności zbierania i przez opis ich istotnych form i typowego przebiegu"”. Innymi słowy, wiedzy o popędzie zbierania dostarcza jedynie opis samego zbierania. Sommer śledzi właśnie proces zbierania i dostrzega przede wszystkim radość (Lust), jaką daje zbieraczom zgromadzenie zbioru rzeczy.

Spójnej odpowiedzi na pytanie, dlaczego zbieramy, nie daje też teoria reliktów. W zbieraniu widzi ona atawizm i dziedzictwo genetyczne. W zamierzchłej przeszłości, mówi się tu, zbieranie było korzystne, a często stanowiło konieczność, jednakże dziś jest bezcelowe. Teoria reliktów operuje pojęciem popędu do zbierania, uznając go za zbędny, lecz trudny czy nawet niemożliwy do wykorzenienia. Toleruje jego formy umiarkowane, jak hobby czy namiętność, ale gdy przybiera on postać pasji uznaje go za niebezpieczny i wymagające leczenia. Zbieracza poucza się, aby zaniechał swych praktyk, gdyż są czymś prymitywnym w naszym nowoczesnym świecie.

Teoria reliktów niewiele w istocie tłumaczy. Jej główna teza ma postać: zbieramy, ponieważ zbieraliśmy. Obecne zbieranie jest konsekwencją naszej przeszłości. Nie potrafiliśmy zaprzestać zbierania we właściwym momencie i pozostało ono z nami jako czynność zbędna. Cierpimy na przymus powtarzania. Należy tu jednak zapytać, mówi słusznie Sommer: jakiego rodzaju czynnością było tamto, wcześniejsze zbieranie? I jeszcze: w jaki sposób pierwotne zbieranie akumulacyjne przetrwało w postaci zbierania estetycznego?

Za redukcjonistyczną uznaje też Sommer teorię, którą nazywa teorią surogatów. Podobnie jak w tamtej, tu również uznaje się, że zbieracz nie wie, co właściwie robi. Za zbieraniem zbieracza, mówią zwolennicy teorii surogatów, skrywają się pragnienia inne niż te widoczne. Zbieranie to wyraz albo symptom czegoś innego. To, co robi zbieracz jest naprawdę jedynie namiastką działania, którego nie może wykonać. Na przykład: zbieracz chce mieć władzę podobną władzy Boga, a ponieważ nie jest w stanie, wykonuje czynności zastępcze: gromadzi rzeczy przynajmniej w wycinku, może nawet reprezentatywnym, i trzyma je niczym swoje królestwo. Tymczasem może właśnie dzięki czynnościom zbierania byliśmy w stanie pojąć ideę wszechmogącego Boga albo wytworzyć ideę jaźni jako jedności.

Obie teorie - teoria reliktów i teoria surogatów - zgadzają się w zasadniczym podejściu do zbierania. Nie pytają, czym ono jest i jak przebiega, lecz zamiast tego

\footnotetext{
${ }^{7}$ Sommer, Zbieranie, 465.
} 
odpowiadają na pytanie, dlaczego w ogóle istnieje coś takiego, jak zbieranie. Zakłada się tu zatem, że fenomen zbierania nie zasługuje na poważne traktowanie, a to, co naprawdę interesujące skrywa się dopiero za nim. Teorie te zatem lekceważą zbieranie, lekceważą również jego odmianę estetyczną, wszędzie dopatrując się drugiego dna i bardziej elementarnej niż deklarowana motywacji.

\section{Homo collector i najczystsza forma zbierania}

Sednem koncepcji Sommera - a właśnie o koncepcji, i to nowatorskiej, należy tu mówić - jest odróżnienie dwóch rodzajów zbierania oraz teza, że pierwsze, czyli akumulowanie ekonomiczne, jest ułomną, podrzędną wersją drugiego, czyli rozróżniającego zbierania estetycznego. Relacja zbierania ekonomicznego do zbierania estetycznego jest relacją zbierania „nieczystego” do „czystego”. Ale i zbieranie estetyczne, rozróżniające, posiada swój terminus ad quem, najwyższy stopień czystości. „Tę najczystszą formę zbierania spotykamy tam, gdzie gromadzone są rzeczy warte zobaczenia, które w ogóle nie istniałyby, gdybyśmy nie byli istotami znajdującymi przyjemność w oglądaniu, to jest rzeczy, które nie tylko są warte zobaczenia, lecz które zostały stworzone wyłącznie dlatego, abyśmy je z przyjemnością oglądali”" . Owe rzeczy to dzieła sztuki. Można o nich powiedzieć, iż są wzorcowymi przypadkami rzeczy wartych zobaczenia. Innymi słowy, wśród różnych wartych zobaczenia rzeczy są takie, które w sposób paradygmatyczny realizują pojęcie rzeczy wartych zobaczenia - i są to właśnie dzieła sztuki. Zostały one stworzone po to, abyśmy mogli oglądać je z estetyczną przyjemnością. Należą tu dzieła z obszaru sztuk plastycznych, ale także dzieła innych rodzajów sztuk, nie przeznaczone do optycznego oglądania, lecz do oglądu i odczytywania ich w inny sposób (dzieła filmowe, muzyczne, literackie).

Przewaga dzieł sztuk plastycznych - obrazów, rzeźb - nad pozostałymi polega na tym, iż są one ciągle obecne dla naszego ujmującego je zmysłu, podczas gdy tamte - symfonie, powieści, filmy fabularne i dokumentalne - trwają co prawda przez czas jakiś, lecz nie trwają stale. Kontemplacja pierwszych nie napotyka praktycznie żadnych ograniczeń. Zatem: „tak, jak wizualne spostrzeżenie jest

\footnotetext{
${ }^{8}$ Tamże, 86.
} 
prototypem oglądu, podobnie przeznaczone dla wzroku dzieło sztuki jest wzorcowym przypadkiem tego, co warte zobaczenia". I dodajmy: a zbieracz dzieł sztuki jest pierwowzorem zbieracza, autentycznym homo collector.

\section{Świat ludzki i narodziny zbierania}

Każdy z nas wie, czym jest zbieranie i każdy potrafi zbierać. Zbieranie jest częścią naszego świata życia (Lebenswelt), czymś znanym nam od dzieciństwa. Badanie fenomenologiczne - jako badanie filozoficzne - wychodzi właśnie od pewnych oczywistości i stara się odnaleźć w ich obrębie obszar tego, co niezreflektowane. Podejście Sommera jest także filozoficzne w innym sensie: zmierza ono do ukazania tego, co podstawowe, ostateczne, czyli do ustalenia fundamentalnych przyczyn zbierania. Gdy idzie o szczegóły metody, autor stara się niczego nie pomijać, lecz objąć analitycznym spojrzeniem wszystkie formy zbierania: począwszy od dzieł sztuki, a na odpadkach skończywszy, sytuując gdzieś pośrodku zbieranie grzybów i znaczków pocztowych.

Więcej aniżeli o etiologii zbierania możemy powiedzieć o jego historii. Pierwszymi zbieraczami byli Adam i Ewa. Żywili się darami natury, które jedynie zrywali i zbierali, aż do zerwania niewłaściwego owocu. Kolejne pokolenia były już zmuszone do życia z pracy rąk i w dużym trudzie. W prehistorii biblijnej znajdujemy też obraz przejścia od sposobu życia nomadów (myśliwych i zbieraczy) do życia osiadłych rolników i hodowców bydła. Rewolucja neolityczna, czyli „wygnanie z raju", o którym mówi teologia, polegała na owym przejściu od receptywnego życia myśliwego do produktywnego rolnika ${ }^{10}$.

Adam i Ewa byli jednak pierwszymi ludzkimi zbieraczami. Zbieranie akumulacyjne, nierozróżniające - związane z opóźnieniem spożycia - spotykamy już bowiem u zwierząt. W historii ludzkości zbieranie - jagód, grzybów, nasion, korzeni, miodu - należało zaś do podstaw sztuki życia. Nie mają racji badacze i feministyczne ideolożki, które twierdzą, że zbieranie było domeną kobiet (figura dającej życie Ewy), zaś mężczyzna był krwiożerczym, agresywnym myśliwym.

\footnotetext{
${ }^{9}$ Tamże, 87.

${ }^{10} \mathrm{Na}$ temat mitów związanych ze Złotym Wiekiem ludzkości i jego odejściem zob. Emil Cioran, Historia i utopia, tłum. i wstępem opatrzył Marek Bieńczyk (Warszawa: Instytut Badań Literackich, 1997), 79-91.
} 
Zbieranie bowiem oznacza w wielu wypadkach także zabijanie (zbieranych ślimaków, raków, dżdżownic), zaś łowy bywają zajęciem angażującym całą wspólnotę, obie płcie. Zresztą, gdy nie ma zwierzyny, myśliwy musi stać się zbieraczem.

Filozofia stara się uczynić zrozumiałym proces zbierania przez odniesienie go do podstawowych danych przebiegu ludzkiego życia. Życie to ma swe obiektywne uwarunkowania. Świat człowieka jest mianowicie uformowany czasowo i przestrzennie, a ponadto dzieli się - według różnych stopni - na to, co znajduje się w tle oraz to, co jest na pierwszym planie. Dla człowieka-zbieracza na pierwszym planie sytuują się rzeczy. Dzięki istnieniu przestrzeni rzeczy mogą zładować się tu lub tam, blisko względem siebie lub wzajemnie oddalone, zaś dzięki czasowi mogą się poruszać albo trwać w miejscu. Przestrzeń, czas i rzeczy tworzą w ten sposób pole, w którym możliwe są stany rozproszenia i bycia obok siebie, a także procesy gromadzenia i rozpraszania.

Pomiędzy obecnym w zbieraniu oglądem i kierującym zbieraniem pojęciem zachodzi stosunek asymetrii. Pojęcie nadaje wprawdzie kierunek spostrzeganiu, jednak spostrzeżenie mieści w sobie zawsze coś więcej i coś innego aniżeli to, ku czemu kierowało je pojęcie. Zachodzi tu najistotniejsza różnica między zbieraniem akumulującym (gathering) i zbieraniem rozróżniająco-estetycznym (collectio). Pierwsze uchwytuje rzeczy bardzo szeroko - jedynie o tyle, o ile odpowiadają one kierującemu zbieraniem pojęciu. Drugie natomiast szuka przedmiotów, które dostarczają spostrzeżeniu zmysłowemu jakąś nadwyżkę oglądu. Zbieranie akumulacyjne zdaje się dlatego trywialne w porównaniu ze zbieraniem estetycznym, choć należy dostrzec, że w dziejach ludzkości to ono pojawiło się jako forma pierwotna zbierania.

\section{Dwa rodzaje zbierania, a właściwie jeden}

Sommer stawia pytanie o to, co sprawia, że zbieranie jest zbieraniem, czyli pytanie o istotę zbierania. Zbieranie w swej czystej formie przebiega według schematu: gromadzenie i oglądanie. Oto liczne przedmioty, które uprzednio były rozproszone, teraz zostają tak poruszone, że następnie znajdują się razem. Owo po- 
ruszenie przedmiotów ku byciu razem motywowane jest pragnieniem ich oglądania. „To, co jest tu-oto, pozostaje tutaj i może być oglądane”11. Nieustanne bycie tu-oto oznacza obecność i trwanie. Ten rodzaj zbierania Sommer określa mianem zbierania estetycznego.

Nieco inaczej wygląda przebieg zbierania, które nazwać można zbieraniem ekonomicznym. Aby posłużyć się przykładem myśliwego: to, co przynosi myśliwy natychmiast znika, bo zostaje zjedzone. Zbieranie ekonomiczne to zatem takie zbieranie, które kończy się zniknięciem tego, co zostało zebrane, nawet jeśli zniknięcie to ulega pewnemu opóźnieniu: „Gromadząc rzeczy, które mają zniknąć, wprowadzamy do procesu przemijania moment trwania. Ekonomiczna funkcjonalizacja trwałego bycia tu oto sprawia, że jest ono tylko opóźnieniem znikania"12. Celem takiego zbierania nie jest już dający radość ogląd, lecz konsumpcja, nie trwanie, lecz zniknięcie. Nie jest to zatem - co słusznie podkreśla filozof - czyste zbieranie, lecz taka jego forma, która w porównaniu ze zbieraniem estetycznym musi zostać uznana za ułomną. Ta przekonująca teza jest zarazem paradoksalna z tego powodu, że - jak wspomniano - w dziejach ludzkości to zbieranie ekonomiczne było pierwotne i dopiero na jego gruncie pojawiło się zbieranie rozróżniające.

Dwa wymienione rodzaje zbierania - jeśli jeszcze przez chwilę chcemy posługiwać się tą dychotomią - ufundowane są na przeciwieństwie zachowywania (conservatio) i niszczenia (annihilatio), przeciwieństwie bytu i nicości. To właśnie prowadzi Sommera do jego głównej tezy:

Jeśli gromadzenie nie łączy się z oglądaniem tego, co nagromadzone, jako pełną formą estetycznego zbierania, to pozostaje jego niższą odmianą, zbieraniem ekonomicznym. Ze sposobu, w jaki ta druga forma zbierania zależy od pierwszej, widzimy, że jest tylko jedno zbieranie: zachowująco-estetyczne. Na poziomie, na którym zanika, zbieranie staje się ekonomiczne, swoją najczystszą odmianę osiąga natomiast w zbieraniu dzieł sztuki ${ }^{13}$.

Ekonomikę znikania przeciwstawić należy estetyce zachowywania. Zbieranie właściwe oznacza bowiem odłożenie konsumpcji i używania: „Tam, gdzie spożywanie (consumptio) zajmuje miejsce przechowywania (conservatio), nie można

\footnotetext{
${ }^{11}$ Sommer, Zbieranie, 5.

${ }^{12}$ Tamże, 85.

${ }^{13}$ Tamże, 5.
} 
mówić o zbieraniu"14. Dlatego właśnie należy uznać, iż istnieje tylko jedno zbieranie, zbieranie estetyczne, czyli zachowujące, zaś zbieranie ekonomiczne jest jego ułomną odmianą. Spoglądając na dzieje ludzkości, przyjdzie jednak przyznać, że zbieranie ekonomiczne poprzedza, i to na długo, zbieranie estetyczne. Wśród ludzi musiało najpierw nastąpić odkrycie tego, co warte oglądania, a następnie rozpocząć się zbieranie dzieł sztuki ${ }^{15}$.

Oglądanie, o którym mowa w wypadku zbierania, oznacza ogląd. Istotnym elementem zbierania estetycznego jest pewien sposób oglądania, a mianowicie długie przyglądanie się. Za jego przeciwieństwo Sommer uznaje nagłe olśnienie, którego formą skrajną jest przeżycie mistyczne. Ogląd nie oznacza wyłączności doświadczenia optycznego, nie wyklucza udziału innych zmysłów, zwłaszcza zmysłu dotyku. Dopowiedzmy, że zwłaszcza posiadacze kolekcji prywatnych pragną nie tylko oglądać, ale też dotykać zebrane przez siebie przedmioty. Możliwość dotykania jest okazaniem prawa własności względem tych rzeczy - inaczej aniżeli w odniesieniu do kolekcji publicznych, muzealnych etc., gdzie dotyk jest zasadniczo wykluczony. Po drugie, dotyk ma charakter hedonistyczny, realizuje przyjemność haptyczną zbieracza. Po trzecie zaś, możemy w dotykaniu przez zbieracza dostrzec przejaw czułości i pietas względem zebranych rzeczy ${ }^{16}$.

Mimo to, u ludzi wzrok zyskał hegemonię, zaś przenoszenie się wertykalne jest dla nas rodzajem samotranscendencji, gdyż nieustannie poszerza horyzonty. Wiele świadczy o tym, iż odczuwamy przyjemność mogąc patrzeć na coś z wysoka, widzieć z góry: szałasy i domki w górach, kolejki linowe, tarasy i wieże widokowe,

${ }^{14}$ Tamże, 299.

${ }^{15}$ Rzecz jasna zbieranie estetyczne dotyczy nie tylko dzieł sztuki jako artefaktów, ale także niektórych rodzajów naturaliów, jak kamienie, minerały, muszle, motyle. Zob. James Delbourgo, Collecting the World. Hans Sloane and the Origins of the British Museum (Harvard: Harvard University Press, 2019). Hans Jonas traktuje obraz - malarską reprezentację widzialnego świata - jako ten rodzaj reliktu, który zaraz obok narzędzia i grobu, a także biżuterii i świątyni, świadczy o tym, iż pochodzi od istoty ludzkiej. Zob. Hans Jonas, Zmiana i trwałość. O podstawach rozumienia przeszłości, tłum. Piotr Domański (Warszawa: IFiS PAN, 1992), 7.

${ }^{16}$ Zagadnienie to jest złożone. Przez czułość rozumiem tutaj zarówno pietyzm - czyli uczucie łączące czułość z szacunkiem, jak w przypadku pamiątek po zmarłych, realizowane w historii antykwarycznej (F. Nietzsche) i określane przez Rzymian mianem pietas - jak też mniej odświętne, zwyczajne i codzienne formy czułości powiązane niekiedy z antropomorfizowaniem rzeczy. Zob. Renata Tańczuk, „Kolekcjonowanie jako doświadczenie haptyczne. Refleksje teoretyczne”, Zbiór Wiadomości do Antropologii Muzealnej 2015, nr 2: 9-28; W kulturze dotyku? Dotyk i jego reprezentacje w tekstach kultury, red. Anna Łebkowska, Łukasz Wróblewski, Patrycja Badysiak (Kraków: Nomos, 2017). 
balony i lotnie... W sumie zaś: „zdolność do horyzontalnego i wertykalnego przenoszenia się jest cielesno-imaginatywną przyczyną tego, że jesteśmy również $\mathrm{w}$ stanie utworzyć spojrzenie obiektywne, a view from nowhere" ${ }^{17}$.

\section{Zbieracz: jego ruchy i jego intencje}

Postać zbieracza może być fascynująca - podobnie jak postać gracza, łowcy przygód, artysty, dandysa, flaneura czy odkrywcy - a to dlatego, iż realizuje on w natężeniu możliwości tkwiące w nas samych. Filozofia chce jednak skupić się na regułach i formach zbierania, chce rozjaśnić, co dzieje się w trakcie tego procesu i co zostaje osiągnięte jako jego rezultat. Docieka metod zbierania, a te występują zawsze, nawet wtedy, gdy zbieranie wkracza w szaleństwo.

Od zbierania intencjonalnego, wiedzionego ludzką wolą, Sommer odróżnia zbieranie jako dzianie się. Woda zbiera się w kałuży, a kurz na książkach. Nie ktoś zbiera tu coś, lecz coś zbiera się. Jest to proces naturalny, pozbawiony intencji ${ }^{18}$. Najlepiej może powiedzieć, iż rzeczy lub materiały, z którymi coś się w takich razach dzieje, nie tyle się zbierają, co nagromadzają ( sich ansammeln). Gdyby bowiem to, co się gromadzi, zbierało się wskutek świadomego działania, wtedy nie nagromadzałoby się, tylko spotykałoby się (sich ver sammeln) ${ }^{19}$.

Intencjonalnemu zbieraniu i zbieraniu się wspólny jest ruch zbierania. Jest on albo czystym procesem, zachodzeniem, wydarzaniem się (das Geschehen),

${ }^{17}$ Sommer, Zbieranie, 202.

${ }^{18}$ „Nikt nie będzie raczej tak twierdził” (Sommer, Zbieranie, 14). Naturalnie niemal nikt nie przypisuje rzeczom intencji i intencjonalnej sprawczości. Napotkać można jednak różne heterogeniczne wierzenia, iż istnieją rzeczy mające moc sprawiania pewnych stanów. Rzeczami takimi są np. fetysze (z portugal. feitico - czynić). Z kolei niektórzy przedstawiciele transhumanizmu sugerują lub twierdzą, iż istnieje „życie rzeczy”, a w literaturze pięknej napotykamy motyw „buntu rzeczy” (choćby u N. Gogola), który ukazuje świat przedmiotowy jako aktywny, zdolny do celowego - z reguły szkodliwego dla człowieka - działania. W kwestii intencjonalności rzeczy zob. Remo Bodei, O życiu rzeczy, tłum. Alicja Bielak, przekład przejrzeli i poprawili Mateusz Salwa i Katarzyna Skórska (Łódź: Przypis, 2016), 56-62.

${ }^{19}$ Wątki te rozwija praca Judith Butler, Zapiski o performatywnej teorii zgromadzeń, tłum. Joanna Bednarek, (Warszawa: Wydawnictwo Krytyki Politycznej, 2016), w której autorka twierdzi, iż celowe gromadzenie się ludzi w przestrzeni publicznej jest - nawet gdy pozbawione jest werbalnego wyrazu aktem znaczącym. Sama obecność werbalnie niemego ciała znaczy. Dlatego ukonstytuowanie się zgromadzenia jest już deklaracją i polityczną aktywnością. 
albo sensownym działaniem, przy czym pierwszy jest podstawą drugiego. I zawsze, jeśli coś się zbiera, to się porusza.

W związku z ruchem, możemy w tym momencie zdefiniować zbieracza: „Zbieracza można zatem w całkiem elementarny sposób pojąć jako kogoś, kto poruszając się samodzielnie, porusza różne inne rzeczy w taki sposób, że to, co przedtem było oddalone, jest teraz razem"20. Zbieracz trzyma coś w dłoni, pod pachą, w ustach albo w kieszeni, a poruszając się porusza także owo coś. Czym zaś okazuje się w tej perspektywie zbieranie? Jeśli ruch, przez który poruszamy inne rzeczy nazwiemy noszeniem, wtedy zbieranie wypadnie nazwać znoszeniem.

Trajektorię ruchów znoszonych rzeczy Sommer określa mianem schematu kolekcjonowania. Jest to gwiaździsty schemat schodzących się ku centrum dróg. Znajdujące się początkowo w rozproszeniu rzeczy poruszają się według tego schematu i zmierzają ku miejscu, gdzie znajdują się blisko siebie. W zbieraniu zbieracz umiejętnie naśladuje to, co ukazuje mu natura: ars imitatur naturam. Zbieranie jest zatem - co nieczęsto podkreślano - aktem mimetycznym.

Także w tym kontekście bez trudu rozpoznajemy dwie formy aktywnego, umyślnego zbierania. Przykładem pierwszej jest zbieranie grzybów, malin, pustych butelek, groszy, używanych worków foliowych, przykładem drugiej - zbieranie numizmatów, rycin, pocztówek, bibliofilskich wydań książek. Wspólne obu formom jest to, że zbierane rzeczy są do siebie podobne, że podpadają pod jedno pojęcie. To pojęcie określa, co zbieramy; i to za sprawą pojęcia rzeczy takie same schodzą się w jednym miejscu. Aspekt, pod jakim rzeczy są podobne może być różny - może to być wygląd rzeczy, ich funkcja, pochodzenie czy historia - ale podobieństwo musi występować. Jeśli ktoś nie potrafi powiedzieć, co zbiera - nie dysponuje odpowiednim wyrazem, a zatem i pojęciem - oznacza to, że nie zbiera niczego.

\section{Obiektywne warunki zbierania}

Nie wszystko daje się zbierać. Zbierać można nie przedmioty po prostu, ale jedynie określony ich rodzaj - rzeczy. Możemy co prawda gromadzić wiele przedmiotów nie będących rzeczami, jednakże, ściśle wziąwszy, zbierać dają się tylko

\footnotetext{
${ }^{20}$ Sommer, Zbieranie, 17.
} 
rzeczy. Sommer wprowadza w tym kontekście istotne filozoficznie odróżnienie rzeczy (Dinge, Sachen) i przedmiotów (Gegenstände). Istnieją rozmaite przedmioty, które nie są rzeczami. Wojna secesyjna, Powstanie Warszawskie, reguła złotego podziału czy liczba dziewięć są przedmiotami, ale nie są rzeczami. Prawdą jest, iż wszystkie rzeczy są przedmiotami - ale nie odwrotnie. Liczby, figury geometryczne, cnoty i wady nie są rzeczami. Dlatego nie mogą się zbierać i nie da się ich zbierać. Rzeczy to ciała, materia. Aby określić, co to jest rzecz najlepiej odwołać się do codziennego doświadczenia. Wtedy można zdefiniować rzeczy jako „przedmioty, które znajdują się w przestrzeni i trwają przez pewien czas. Muszą one wypełniać określoną przestrzeń, a zatem mieć pewną objętość; muszą być ograniczone, posiadać określającą je formę; muszą też istnieć przez pewien czas”21.

Nie można zbierać jednej rzeczy, lecz tylko wiele. Skądinąd sposób, w jaki wiele rzeczy jest wieloma, stanowi ważny problem. Jak wiele musi być rzeczy, aby dały się zbierać? Dwie to jeszcze za mało, zatem trzy. Tres faciunt collectionem. Zbioru nie tworzą nigdy mniej aniżeli trzy rzeczy. Podobnie: dwie osoby mogą się spotkać, ale zebrać dopiero trzy. Potrzebne jest też, aby dysponować pojęciem, bo tylko ten, kto wie, co się zebrało może zauważyć, że się zebrało.

Zbieranie tego, co jest wielością - na wiele sposobów - wymaga trwałych rzeczy w celu ich zbierania. To, co płynne i lotne (oleje, gazy) oraz to, co jest niematerialnym sensem (powieści, poezja, symfonie) potrzebuje pojemników - w pierwszym przypadku - i materialnych nośników - w drugim. Zarazem nośnik (papier, płyta, taśma albo chip) zwielokrotnia zapisany sens ${ }^{22}$. Zbierane rzeczy, dalej, muszą być ruchome. Lasy, jeziora, domy ani ruiny nie są podatne na zbieranie. Niektóre rzeczy trzeba wykopać, np. jadalne bulwy albo archeologiczne zabytki, inne musimy w celu zbierania zerwać, np. śliwki z drzewa.

O zbieraniu mówimy też w sensie przenośnym, a mianowicie wtedy, gdy twierdzimy, że zbieramy doświadczenia żyjąc czy podróżując lub że zbieramy

${ }^{21}$ Tamże, 108.

${ }^{22}$ „Pośrednio zbierać można [...] to, co nie-rzeczowe: materię, która nie jest wyraźnie oddzielona, zdarzenia, które nie trwają, rodzaje i jednostki sensu (Sinngebilde), które w ogóle nie mogą występować w przestrzeni. Tego rodzaju nierzeczowe przedmioty zbieramy przez nagromadzenie rzeczowych pojemników, nośników lub reprezentantów, które je w różny sposób zawierają lub przedstawiają i którym zawdzięczają one, w odpowiednio różny sposób, swą podatność na zbieranie" (Sommer, Zbieranie, 129). To, co nie jest rzeczą, musi zostać urzeczowione w celu jego zbierania. Co do pojemników, to preferujemy szklane, a w każdym razie przezroczyste, nośniki zaś preferujemy płaskie i notorycznie redukujemy ich wymiary. 
punkty w czasie gry ${ }^{23}$. Zbieranie jest ponadto bardzo ważną metaforą w kontekście opisu naszej jaźni. Jeśli swego ciała doświadczam jako całości i uznaję, iż jest ono rzeczą, to inaczej jest z jaźnią. Dystrakcja jest tu jeśli nie normą, to zjawiskiem bardzo częstym. Bywamy też nieobecni duchem, senni, zmęczeni czy oszołomieni. W takich sytuacjach usiłujemy się skupić, zebrać w sobie, zastanowić. Nie jest to łatwe, zważywszy na dwie grupy czynników rozpraszających. Pierwsza wiąże się z działaniem zmysłów, których jest wiele i które często współzawodniczą o naszą uwagę poszukując bodźców dla siebie ${ }^{24}$. Druga to czynniki związane ze świadomością, której niejako sami przyzwalamy na rozproszenie. Jego przeciwieństwo bowiem, skupienie, męczy nas, wymaga poświęcenia energii. Do tego dochodzi zmienność emocji i uczuć, które wywołują w nas rzeczy. Rozproszenie powodowane jest wreszcie przez czasowy charakter naszego istnienia: usiłujemy zatrzymać to, co mijające oraz scalić poszczególne sekwencje życia, aby utrzymać tożsamość $\mathrm{w} \mathrm{ruchu}^{25}$.

\section{Homo videns i rzeczy warte zobaczenia}

Osią koncepcji niemieckiego fenomenologa jest, jak już wiadomo, odróżnienie dwóch rodzajów zbierania. Przyjrzyjmy się im teraz bliżej w kontekście pojęcia tego, co estetyczne. Jakie zachodzą między nimi relacje?

${ }^{23}$ Zob. np. Sean Curran, On Sexuality - Collecting Everybody's Experience (Edinburgh: Museum Etc, 2016). Doświadczenia erotyczne z mężczyznami zbiera niepokojąca młoda bohaterka filmu La collectionneuse (1967) przedstawiciela francuskiej Nowej Fali Erica Rohmera. Jest ona właśnie akumulującą zbieraczką, a nie rozróżniającą kolekcjonerką, jak początkowo sądzą adorujący ją mężczyźni.

${ }^{24}$ Wraz z rozwojem cywilizacji liczba czynników rozpraszających naszą uwagę stale wzrasta. Zob. Tim Edensor, „The Social Life of the Senses: Ordering and Disordering in Modern Sensorium”, w: A Cultural History of the Senses, Vol. 6: In the modern age, red. David Howes (London: Bloomsbury Academic, 2014), 31-53.

${ }^{25}$ Te ostatnie praktyki związane były $\mathrm{z}$ takimi rodzajami literackimi jak autobiografia, dziennik, esej, a także powieść. W pismach tych człowiek powraca do siebie ze stanu rozproszenia przeszłego lub obecnego. Zbiera się tu siebie - w jedność - a nie rzeczy. Coś zatem, czego nie można zbierać schodzi się w jednym miejscu, na podobieństwo schodzących się rzeczy i to schodzenie staje się wzorcem rozumienia, a także przedstawiania tego, co się dzieje albo co się zrobiło. Zob. Erin Plunkett, A Philosophy of the Essay. Scepticism, Experience and Style (London: Bloomsbury Academic, 2018). 
Zbieranie akumulacyjne jest w najwyższym stopniu nieestetyczne. Jest ono istotnie określone przez fakt, że ten, kto zbiera, nie interesuje się daną w oglądzie różnorodnością lub nie jest na nią wrażliwy. Charakterystyczny jest tu deficyt oglądu. Zbieranie w swej integralnej postaci jest estetyczno-odróżniające: zbieranie ekonomiczno-akumulacyjne jest jego wybrakowanym wariantem ${ }^{26}$.

Pomiędzy pojęciami collecting i gathering zachodzi poważna asymetria. Pierwsze akcentuje ogląd, w drugim wymiar oglądu jest silnie zredukowany. Nie jest zatem prawdą, że oba rodzaje zbierania - ekonomiczno-akumulacyjne i estetyczno-odróżniające - są dwoma niezależnymi i równouprawnionymi rodzajami gromadzenia: „' gathering' jest niepełną odmianą, 'wybrakowanym modusem' collecting. Gatherer to collector, który nie zauważa subtelnych różnic"27. Pierwsze zbieranie jest „nieczyste”, drugie jest „czystym” zbieraniem.

Zbieraniem rozróżniającym kieruje ciekawośćc ${ }^{28}$. „Dziwne jest to, czemu się dziwimy; osobliwe jest to, co oddzielamy od innych rzeczy; kuriozalne jest to, co budzi naszą ciekawość (curiositas); rzadkie jest to, co rzadko spotykamy. Podobnie ma się rzecz z tym, co jawi nam się jako niewiarygodne lub niezwykłe, zaskakujące i zadziwiające"29.

Aby zbieranie estetyczne było możliwe, rzeczy takie muszą być rzadkie, lecz nie nazbyt rzadkie. Dopiero wtedy może dojść do powtarzającego się ich zachowywania. „Każda rzecz związana jest z pojęciem, pod które podpada; i tylko dlatego, że tak bardzo różni się od pozostałych rzeczy, które również podpadają pod to pojęcie, zaskakuje lub wywołuje zdziwienie. I tylko dlatego jest przechowywana” ${ }^{30}$. I tu właśnie wprowadza Sommer pojęcie estetyczne, które ujmuje swe obiekty w całej ich różnorodności. Jest to mianowicie pojęcie „tego, co godne oglądania” lub „tego, co warte zobaczenia”. Ku takim rzeczom - rzeczom podpadającym pod owo pojęcie - kieruje się zbieranie estetyczne. Każdy, kto zachowuje ta-

${ }^{26}$ Sommer, Zbieranie, 46.

${ }^{27}$ Tamże, 47.

${ }^{28}$ Sommer przyznaje, że istnieje zależność pomiędzy reaktywnością na pewne różnice a warunkami historycznymi, kulturowymi i oczywiście indywidualnymi. Analizę religijno-politycznego kontekstu curiositas na przykładach daje główne dzieło mistrza Sommera Hansa Blumenberga Prawowitość epoki nowożytnej, tłum. Tadeusz Zatorski, naukowo opracował Mateusz Falkowski (Warszawa: PWN, 2019), 279-563.

${ }^{29}$ Sommer, Zbieranie, 54.

${ }^{30}$ Tamże, 77. 
kie przedmioty, jest też w stanie zrozumieć, co mają wspólnego: znajduje ich pojęcie. Dlatego finałem odkrycia tego, co warte zobaczenia, jest odkrycie pojęcia tego, co warte zobaczenia. Sommer pisze:

Coś może być zatem: godne uwagi, czarujące, piękne, zadziwiające, cudowne, niesłychane, niepojęte, fantastyczne, fenomenalne, dowcipne ... - i warte zobaczenia. Pojęcie tego, co warte zobaczenia, jest w tym towarzystwie tylko primus inter pares. O ile jednak jest ono jedynym, które może zastępować wszystkie te 'estetyczne pojęcia', o tyle też jest częścią, która wyraża całość: pars pro toto ${ }^{31}$.

Analizy naszego poznawania i zbierania pokazują, że jako ludzie mamy w sobie nienasyconą tęsknotę za bezpośrednim oglądem, za doznawaniem owej optycznej rozkoszy, którą daje widok pięknych i/lub niezwykłych rzeczy. Homo videns jest zarówno gapiem, jak i kontemplatykiem.

Po wprowadzeniu tych dystynkcji możemy zdefiniować to, co estetyczne: „to, co jest zbierane estetycznie, jest sumą pojęcia tego, co warte zobaczenia, $i$ jakiegoś innego pojęcia"32. Jeśli jakiemuś zbiorowi obiektów brakuje owego drugiego pojęcia, pojęcia organizującego, wtedy jest on tylko przypadkową estetyczną zbieraniną (która może wszak zawierać bardzo cenne obiekty). Takimi zbiorami były dawne Wunderkammern. Zbieranie estetyczne kulminuje w zbieraniu dzieł sztuki. Te ostatnie są paradygmatycznymi przypadkami rzeczy wartych zobaczenia. Są to wszak obiekty, które zostały wytworzone jedynie w tym celu, abyśmy mogli je oglądać z estetyczną przyjemnością.

\section{Ciekawość i fenomeny graniczne}

Ciekawość ludzką budzą zarówno obiekty pozostające w granicy wyznaczonej przez ich pojęcie, jak i obiekty, które sytuują się na jego granicy. Co do pierwszych, to za godne zobaczenia uznajemy te obiekty, które swoje pojęcie egzemplifikują w sposób szczególnie klarowny, paradygmatyczny. Mamy wtedy do czynienia z przypadkiem modelowym, wzorcem, typowym przykładem, X par excellence, kat' exochen. Tu rzecz jest tym, czym ma być, a nie zdarza się to często. Czy

\footnotetext{
${ }^{31}$ Tamże, 78.

${ }^{32}$ Tamże, 84.
} 
istnieją obiekty, które można uznać za paradygmatyczne przykłady ruiny albo np. wraku i które budzą naszą ciekawość z tego właśnie powodu? Otóż, ruina lub wrak należą do obiektów reprezentujących granice pojęcia, a fascynacja nimi wynika właśnie $\mathrm{z}$ owej graniczności ${ }^{33}$. To właśnie przy granicy i na granicy znajdujemy wiele tego, co osobliwe, kuriozalne, niespotykane.

Do fenomenów granicznych zalicza się też to wszystko, co jest dwuznaczne, trudne lub niemożliwe do zaklasyfikowania, wszystko, czego nie potrafimy jednoznacznie przyporządkować. Wszystko to niepokoi nas, ponieważ stawia pod znakiem zapytania ustabilizowany pojęciowo porządek, wprowadza weń zamieszanie i grozi jego zniszczeniem. Zauważamy, że ostateczne pewniki nie istnieją: grunt, na którym stoimy, staje się chwiejny, a ustanowione przez nas granice niepewne. Ale tremendum, które nas przeraża, jest zarazem fascinosum, które nas przyciąga, więcej: przykuwa $^{34}$.

Wszystko to: opustoszałe budynki, łuszcząca się z ich ścian farba, oleiste zacieki na posadzce w ich wnętrzach, wilgoć, rozchodzący się tam zapach butwiejącej materii, porzucone w nich zniszczone przedmioty, np. narzędzia, dziecięce zabawki, podarte dokumenty, wypaczone oddziaływaniem wilgoci meble wszystko to budzi w nas niepokój, bo stanowi wyrwę w świecie budowanym na ideologii postępu i racjonalnego porządku. W takim świecie nawet resztki konsumpcyjne powinny być uprzątnięte na czas, nie powinny zalegać i mącić widoku atrakcyjnego życia ani też stanowić potencjalnego źródła zakażeń dla ludzi. Tymczasem budowany przez ludzi świat podlega korozji na naszych oczach. Podatność na destrukcję jest metafizycznie wpisana w każde ludzkie dzieło - tempus edax rerum - a widniejące przed nami opuszczone budynki, ruiny i zniszczone przedmioty stanowią niepokojące memento tej zasady.

W świetle powyższych uwag staje się może zrozumiałe, że ujemnie nacechowane zaciekawienie może budzić także to, co piękne. W ustawicznie rozpadającym się świecie wzorcowe piękno jest niejako skandaliczne (gr. skandalon - zgorszenie), stanowi wyrwę i przypadek skrajny. Zatem: „to, co może być piękne i wzorcowe, może być również - właśnie z tego powodu - całkiem inne: nieatrakcyjne, brzydkie, niesmaczne lub też nieudane, poronione, sfuszerowane. I chociaż

\footnotetext{
${ }^{33}$ Zob. Georg Simmel, „Ruina. Próba estetyczna”, w: Georg Simmel, Most i drzwi. Eseje wybrane, tłum. Małgorzata Łukasiewicz (Warszawa: Oficyna Naukowa, 2006), 169-176.

${ }^{34}$ Sommer, Zbieranie, 84.
} 
brzmi to paradoksalnie, to również takie rzeczy możemy oglądać z taką samą ciekawością, z jaką czasami oglądamy złom i rumowiska, brud i śmieci, padlinę i zgliszcza, odpady i nawóz" ${ }^{35}$.

\section{Uwagi krytyczne}

Na koniec kilka uwag krytycznych o koncepcji Sommera. W koncepcji filozofa zasadniczo brak fenomenologii zmysłów innych aniżeli wzrok, zwłaszcza fenomenologii dotyku, wrażeń haptycznych. A przecież charakteryzowany przez Sommera współczesny design bierze takie wrażenia silnie pod uwagę ${ }^{36}$. Człowiek to nie tylko homo videns. Sommer przyznaje co prawda, że pojęcie oglądu - fundamentalne dla odbioru przedmiotów estetycznych - jest „tylko prototypem i ogólnym określeniem wszystkich form bezpośredniej obecności przedmiotów”37. Mimo tej świadomości wywód filozofa niemal pomija pozaoptyczne formy oglądu rzeczy.

Druga kwestia dotyczy rzeczy rzadkich, obiektów atopicznych. Sommer pisze o rzeczach rzadkich: „Za możliwość jej oglądania jesteśmy gotowi zapłacić, a jeszcze więcej jesteśmy gotowi zapłacić za możliwość jej pokazywania"38. Spostrzeżenie to jest trafne w odniesieniu do niektórych wypadków ludzkiej próżności - np. kupowania drogich ubrań czy galanterii (damskie torebki!) od wybitnych projektantów - ale jako zasada ogólna jest w swym drugim członie fałszywa. Zbieracze i kolekcjonerzy mają często problemy ze znalezieniem powierzchni pokazowej dla swych zbiorów. Aby powstała wystawa, muszą najpierw znaleźć kuratorów i miejsce, rozeznać się w gronie możliwych jej odbiorców etc. Zajmuje to sporo czasu, a sukces przedsięwzięcia i tak jest niepewny. Co zresztą miałoby nim być? Dla kolekcjonerów zapłatą za ich trud wyboru i zbierania jest możliwość wywoływania podziwu u odbiorców oraz możliwość ich edukowania. O tym ostatnim motywie rzadko się pamięta. U podstaw kolekcjonerstwa nie leży zatem próżność

35 Tamże, 82.

36 Zob. Tricky Design. The Ethics of Things, red. Tom Fisher, Lorraine Gamman (London: Bloomsbury Academic, 2019).

${ }^{37}$ Sommer, Zbieranie, 78.

38 Tamże, 87-88. 
- choć i ona jako wada powszechnoludzka nieobca jest wielu kolekcjonerom ${ }^{39}$ lecz chęć ocalania tego, co warte oglądania. Warto podać choćby przykład F. Jasieńskiego (1861-1929) w Polsce, wybitnego zbieracza japoników, który zasadniczo nie miał komu pokazać, a nawet przekazać swoich zbiorów, ponieważ mało kto we współczesnej mu Polsce rozumiał ich wartość i był w stanie je podziwiać.

Trzecia kwestia dotyczy ozdób. Otóż, nie jest jedynie tak, jak twierdzi autor, iżby stosowanie ozdób było motywowane kierowaniem uwagi na owe piękne rzeczy, a poprzez nie na nas jako na ich nosicieli. Taka uwaga może dotyczyć co najwyżej biżuterii bardzo oryginalnej (np. naszyjników Elsy Schiaparelli) lub o dużym ładunku ekscentryczności. Zasadniczo ozdoby nie wiszą na nas jak na choinkach - choć i to się zdarza - lecz tworzą z ludzkim ciałem jedność estetyczną ${ }^{40}$. Dłoń z palcami o nałożonych pierścieniach jest pewną całością. Gustownie przyozdobiona biżuterią kobieta nie jest nosicielką naszyjnika, kolczyków i bransoletek, lecz przyozdobioną postacią, której urok estetyczny odbieramy jako urok całości. Innymi słowy, delektujemy się całą postacią, a nie - poza szczególnymi przypadkami, np. podczas specjalistycznej dyskusji estetyków lub w fetyszystycznej fascynacji - jej fragmentami. Uwaga ta dotyczy też przyozdobionych mężczyzn.

Powtórzmy: przyozdobiona postać jest dla nas, postrzegających ją, całością, podobnie jak całością jest człowiek-myśliwy z harpunem lub przemieszczający się nocą człowiek-biegacz z latarką przytwierdzoną do czoła. Uwagę tę można poszerzyć o postrzeganie drugiego człowieka i jego ciała w ogóle. Ciało to dane mi jest nie w sposób statyczny, jako nieruchomy obiekt - wyjąwszy pewne konteksty lecz dane mi jest w ruchu i wyrazowości. Dane mi jest też jako pewna całość, której dynamikę odczuwam w sposób bezpośredni.

\footnotetext{
${ }^{39}$ Nie jest łatwo stwierdzić, czy właściwa kolekcjonerom chęć pokazania siebie poprzez swoją kolekcję - starannego kreowania swojej tożsamości za jej pomocą - jest wyrazem próżności czy pragnienia ekspresji. Na ten temat zob. Agata Kubala, Filhellenizm a rodząca się nowoczesność. Kolekcja starożytności Eduarda Schauberta w świetle zachodzących zmian (Kraków: Księgarnia Akademicka, 2020). Schaubert (1804-1860) był wykształconym w Berlinie u Karla F. Schinkla wrocławskim architektem, który podczas dwudziestoletniego pobytu w Grecji - gdzie obejmował stanowisko naczelnego architekta Aten $-\mathrm{z}$ filhelleńskich pobudek zgromadził cenną kolekcję antyków (ponad 300 obiektów, m. in. wazy, figury i lampy z terakoty, brązy, gemmy, monety), przekazaną potem wrocławskiemu Królewskiemu Muzeum Sztuki i Starożytności. Wśród intencji Schauberta jako zbieracza było pragnienie wykreowania swego wizerunku poprzez kolekcję.

${ }^{40}$ Zob. Jan Kurowicki, Dlaczego ozdoba zdobi (wykłady z estetyki i filozofii kultury dla artystów i ekonomistów) (Warszawa: Dom Wydawniczy Elipsa, 2006).
} 
W tym kontekście widać, iż autor zbyt słabo dostrzega fakt, iż zrastamy się z przedmiotami, że tworzymy wraz z nimi pewne całości. Dotyczy to zwłaszcza narzędzi i ozdób, choć - jak pokazały prace B. Latoura - nie tylko. Sommer pisze o rzeczach jako o obiektach oddzielonych od nas: trzymanych, noszonych, przypinanych etc. Tymczasem pod pewnymi względami człowiek-z-latarką jest pewną całością, podobnie jak człowiek-w-masce; dotyczy to zasadniczo ludzi wyposażonych w narzędzia. I tak właśnie postrzegamy ludzi z narzędziami - jako pomnożone narzędzia - a opis fenomenologiczny musi zdawać sprawę z tego doświadczenia.

Charakteryzując pamięć jako pojemnik służący gromadzeniu i przechowywaniu doświadczenia ${ }^{41}$, Sommer zdaje się nie brać pod uwagę tak istotnej dla ludzi potrzeby zapominania i służącej jej ars oblivionis. Jest przecież tak, że - jak uczyli już starożytni, a przypomniał to F. Nietzsche w rozprawie O pożytkach i szkodliwości historii dla życia (1874), zaś bardziej współcześnie M. Augé - życie wymaga zarówno pamięci, jak i niepamięci minionych zdarzeń i przeżyć. Aby żyć, trzeba umieć zapominać, inaczej minione przeżycia mogą stać się brzemieniem zbyt ciężkim, które utrudni dalsze życie.

Brakuje w wywodach niemieckiego fenomenologa porywających przykładów zbierania dzieł sztuki, a także przykładów kolekcji i obiektów wartych oglądania. I nie chodzi o elitarny dystans wobec trywialnych rodzajów i trywialnych obiektów zbierania, lecz o ... sprawiedliwość. O sprawiedliwości bowiem pisze sam autor jako o tym, co jesteśmy winni rzeczom wartym oglądania. Takimi zaś rzeczami są w najwyższym stopniu przedmioty określane mianem arcydzieł. Analizy Sommera są skupione na przeżywanym świecie życia codziennego, Lebenswelt, a w jego obrębie kolekcjonerstwo estetyczne nie pojawia się z reguły na pierwszym planie. Jest ono jednak jednym z najbardziej chlubnych ludzkich zatrudnień, a arcydzieła są tym, co wystawia ludzkości jedno z najlepszych świa$\operatorname{dectw}^{42}$. Nastrój rozważań autora o wiele by się zatem podniósł, gdyby wpleść nie analizy gromadzenia, aranżacji wystaw i oglądu arcydzieł, zwłaszcza malarstwa.

${ }^{41}$ Sommer, Zbieranie, 334-341.

${ }^{42}$ Zob. Walter Kahn, Arcydzieła. Studia z historii pojęcia, tłum. Piotr Paszkiewicz (Warszawa: PWN, 1988). 
Nieprawdziwa jest teza Sommera, iż dzieła sztuki to rzeczy, które zostały wytworzone jedynie w tym celu, abyśmy mogli je oglądać z estetyczną przyjemnością ${ }^{43}$. Wiele $\mathrm{z}$ tych dzieł bowiem powstało $\mathrm{z}$ ambicji poznawczych: miały być pewnym odczytaniem rzeczywistości i jako takie roszczą sobie prawo do prawdziwości. Nawet portrety malarskie są często studiami psychologicznymi, podobnie jak studia pejzażu. Owszem, to, że dzieła takie „idą w świat” oznacza, iż ich twórca pragnie znaleźć odbiorców, dotrzeć do ludzi, którzy przyjmą jego interpretację lub wejdą z nią w polemikę. Dzieło ma jednak często intencje poznawcze. Autor przeocza ten fakt, co dziwi tym bardziej, że przez dzieła sztuki rozumie on nie tylko obrazy i rzeźby, ale także dzieła muzyczne i literackie. Zwłaszcza zaś te ostatnie są podatne na interpretację prawdziwościową ${ }^{44}$.

Analizując przygotowania zbieracza do wyjścia i namysł nad środkami na drogę, Sommer pisze: „To, czy ktoś wyrusza dopiero pierwszy raz, czy też pokonuje swoją drogę od 100, 1000 czy 100000 lat, niewiele zmienia, jeśli chodzi o to, czego potrzebuje lub czego mógłby potrzebować; jeśli coś się zmienia, to raczej to, co ma lub co może mieć" ${ }^{35}$. Zakłada się tu stałość ukształtowania istoty ludzkiej, jej zasadniczą ahistoryczność. Jest to mocne założenie. I ile bowiem zgodzimy się, że istota ludzka sprzed stu tysięcy lat tak samo jak my potrzebowała jakiegoś środka służącego jako bandaż do opatrywania ran, to nie jest już równie oczywiste, że tak jak my potrzebowała zabierać w podróż rzeczy do rozpraszania nudy. Nie wiemy tego.

Należałoby jeszcze zauważyć, że wszechstronna koncepcja Sommera bardzo mało uwagi poświęca tak istotnej kwestii, jak czynność obdarowywania i fenomen daru. Obdarowywanie należy do pradawnych rytuałów, oznacza kulturę i jest spoiwem społecznym, może najsilniejszym. Aby móc obdarować, należy wcześniej zebrać, dlatego mówiąc o gromadzeniu nie należy zapominać o związkach tych praktyk. Podobnie, jak należałoby poszerzyć fenomenologię zbierania o fenomenologię obdarowywania ${ }^{46}$, należałoby się w niej też odnieść do zjawiska wymiany, które jest nieodłączne od życia w kulturze zbierackiej i każdej kulturze rozwiniętej.

${ }^{43}$ Sommer, Zbieranie, 86.

${ }^{44}$ Zob. Władysław Stróżewski, O prawdziwości dzieła sztuki. Prawdziwościowa interpretacja dzieła sztuki literackiej, w: Władysław Stróżewski, Wokół piękna. Szkice z estetyki (Kraków: Universitas, 2002), $174 \mathrm{i} \mathrm{n.}$

${ }^{45}$ Sommer, Zbieranie, 258.

${ }^{46}$ Kwestia daru jest żywo podejmowana we współczesnej filozofii, stanowiąc centralny punkt myśli takich autorów, jak Jacques Derrida, Emmanuel. Levinas, Michel Henry, Jean-Luc Marion, Claude 


\section{Podsumowanie}

Sumując, koncepcja Sommera jest bardzo wszechstronna i bogata. Stanowi ona fenomenologię najważniejszych ludzkich praktyk, które możemy obserwować w świecie życia oraz zbiór licznych i wspartych dobrymi argumentami hipotez co do tego, jak owe praktyki mogły przebiegać w dalekiej przeszłości.

Fundamentem koncepcji Sommera jest odróżnienie dwóch rodzajów zbierania: akumulacyjnego i rozróżniającego. Zbieraniem par excellence jest zbieranie dzieł sztuki. Te ostatnie są przedmiotami, które są oglądane, badane i interpretowane i które od innych przedmiotów poddawanych takim zabiegom różni to, że są one przeznaczone do zbierania. Dlatego muzealnictwo jest dla historii sztuki tym, czym archiwistyka i dokumentalistyka jest dla historii.

Tym, co otrzymujemy od filozofa są jednak nie tylko liczne szczegółowe analizy i typologie, ale rozległa wizja antropologiczna. W wizji tej człowiek jawi się jako homo collector. Jest mianowicie istotą, której życie przepełniają rozmaite praktyki zbierania, a ich postacią wzorcową jest rozróżniające, wrażliwe na szczegóły rzeczy zbieranie estetyczne. Analizując wynalezienie duszy czy nową agrarną świadomość siebie połączoną z wynalazkiem pisma i wzorowaniem na nim struktury społecznej filozof oferuje zręby poważnej antropologii historycznej.

Dobrze uzasadniona i bliska większości kolekcjonerów jest wreszcie konkluzja rozważań Sommera. Według niej, pragnieniem, które niesie od wewnątrz czynności zbierania i skupiania jest pragnienie trwałej obecności tych wszystkich wspaniałych rzeczy, których oglądanie daje nam radość i szczęście. Owo pragnienie trwającego oglądu łączy się z pragnieniem zachowania samego siebie w oglądzie: „Jest to zachowanie samego siebie na sposób i poprzez medium oglądania”" Innymi jeszcze słowy, kolekcjoner który zbiera rzeczy i któremu ogląd zebranych $\mathrm{w}$ trybie estetycznym rzeczy sprawia radość pragnie zachować owe rzeczy - wraz z samym sobą - „na zawsze”48.

Lefort czy Vincent Descombes. O ile w koncepcjach wymienionych filozofów akcentuje się bezinteresowność daru, to w klasycznych ujęciach antropologicznych, zwłaszcza Marcela Maussa, dar jest czymś, co zobowiązuje do odwzajemnienia stanowiąc przez to spoiwo międzyludzkie i fundament długotrwałych społecznych relacji. Zob. Marcel Henaff, The Philosopher's Gift. Reexamining Reciprocity, tłum. Jean-Louis Morhange (Fordham: Fordham University Press, 2019).

${ }^{47}$ Sommer, Zbieranie, 9.

${ }^{48}$ Tamże, 467. 


\section{Bibliografia}

Beinke, Lothar. Sammeln und Sammler. Tönningen: Der Andere Verlag, 2005.

Belk, Russell. Collecting in a Consumer Society. London: Routledge, 2001.

Blom, Philipp. Sammelwunder, Sammelwahn. Szenen aus der Geschichte einer Leidenschaft. Frankfurt am Main: Eichborn, 2004.

Blom, Philipp. To Have and to Hold. An Intimate History of Collectors and Collecting. New York: Overlook Press, 2003.

Blumenberg, Hans. Prawowitość epoki nowożytnej. Tłum. Tadeusz Zatorski, naukowo opracował Mateusz Falkowski. Warszawa: PWN, 2019.

Bodei, Remo. O życiu rzeczy. Tłum. Alicja Bielak, przekład przejrzeli i poprawili Mateusz Salwa i Katarzyna Skórska. Łódź: Przypis, 2016.

Butler, Judith. Zapiski o performatywnej teorii zgromadzeń. Tłum. Joanna Bednarek. Warszawa: Wydawnictwo Krytyki Politycznej, 2016.

Cioran, Emil. Historia i utopia. Tłum. i wstępem opatrzył Marek Bieńczyk. Warszawa: Instytut Badań Literackich, 1997.

Curran, Sean. On Sexuality - Collecting Everybody’s Experience. Edinburgh: Museum Etc, 2016.

Delbourgo, James. Collecting the World. Hans Sloane and the Origins of the British Museum. Harvard: Harvard University Press, 2019.

Edensor, Tim. The Social Life of the Senses: Ordering and Disordering in Modern Sensorium, W: A Cultural History of the Senses, Vol. 6: In the modern age. Red. David Howes, 31-53. London: Bloomsbury Academic, 2014.

Henaff, Maurice. The Philosopher's Gift. Reexamining Reciprocity. Tłum. Jean-Louis Morhange. Fordham: Fordham University Press, 2019.

Jonas, Hans. Zmiana i trwałość. O podstawach rozumienia przeszłości. Tłum. Piotr Domański. Warszawa: IFiS PAN, 1992.

Kahn, Walther. Arcydzieła. Studia z historii pojęcia. Tłum. Piotr Paszkiewicz. Warszawa: PWN, 1988.

Kubala, Agata. Filhellenizm a rodząca się nowoczesność. Kolekcja starożytności Eduarda Schauberta w świetle zachodzących zmian. Kraków: Księgarnia Akademicka, 2020.

Kurowicki, Jan. Dlaczego ozdoba zdobi (wykłady z estetyki i filozofii kultury dla artystów i ekonomistów). Warszawa: Dom Wydawniczy Elipsa, 2006.

Napiórkowski, Marcin. „Co zbierają nasze dzieciaki”, Tygodnik Powszechny 2019, nr 31: $12-16$.

Plunkett, Erin. A Philosophy of the Essay. Scepticism, Experience and Style. London: Bloomsbury Academic, 2019.

Pomian, Krzysztof. Kolekcjonerstwo i filozofia. Narodziny nowożytnego muzeum. W: Krzysztof Pomian, Drogi kultury europejskiej. Trzy studia, 113-165. Warszawa: IFiS PAN, 1996. 
Pomian, Krzysztof. Zbieracze i osobliwości. Paryż-Wenecja. XVI-XVIII wiek. Tłum. Andrzej Pieńkos. Gdańsk: Słowo/Obraz Terytoria, 2012.

Simmel, Georg. „Ruina. Próba estetyczna”. W: Georg Simmel. Most i drzwi. Eseje wybrane. Tłum. Małgorzata Łukasiewicz, 169-176. Warszawa: Oficyna Naukowa, 2006.

Sommer, Andreas U., Dagmar Winter, Miguel Skirl. Die Hortung. Eine Philosophie des Sammelns. Düsseldorf: Parerga Verlag, 2000.

Sommer, Manfred. Zbieranie. Próba filozoficznego ujęcia. Tłum. Jarosław Merecki. Warszawa: Oficyna Naukowa, 2003.

Stróżewski, Władysław. „O prawdziwości dzieła sztuki. Prawdziwościowa interpretacja dzieła sztuki literackiej”. W: Władysław Stróżewski. Wokół piękna. Szkice z estetyki, 174-198. Kraków: Universitas, 2002.

Tańczuk, Renata, „Kolekcjonowanie jako doświadczenie haptyczne. Refleksje teoretyczne”, Zbiór Wiadomości do Antropologii Muzealnej 2015, nr 2: 9-28.

The Cultures of Collecting. Red. John Elsner, Roger Cardinal. Cambridge, Mass.: Harvard University Press, 1994.

Tricky Design. The Ethics of Things. Red. Tom Fisher, Lorraine Gamman. London: Bloomsbury Academic, 2019.

W kulturze dotyku? Dotyk i jego reprezentacje w tekstach kultury. Red. Anna Łebkowska, Łukasz Wróblewski, Patrycja Badysiak. Kraków: Nomos, 2017.

\section{Summary}

\section{Manfred Sommer's Philosophy of Gathering}

This paper is devoted to the discussion of Mannfred Sommer's philosophy, particularly his phenomenology of the practice of gathering. Sommer's conception is underlaid by the distinction between an economical gathering and an aesthetical gathering. Whereas the former can be described as an accumulation that is nondifferential in its nature, the latter is essentially differential - it is directed towards individual features of the object. However, on the closer consideration the economical gathering turns out to be imperfect and incomplete form of the aesthetical gathering. Gathering as well as collecting stem from the fundamental fact that we are homo videns - beings that find the ultimate joy in the activity of seeing. As homo videns we also desire that this activity should last forever. The paper ends with the discussion of the critical remarks upon Sommer's philosophy.

Keywords: gathering; collecting, thing 


\section{Zusammenfassung}

\section{Manfred Sommers Philosophie des Sammelns}

Der Artikel ist der Philosophie von Manfred Sommer und seiner Phänomenologie der Sammelpraktiken gewidmet. Die Grundlage des Entwurfs von Sommer bildet die Unterscheidung von ökonomischem und ästhetischem Sammeln. Das ökonomische Sammeln hat den Charakter einer nicht unterscheidenden Kumulation. Das ästhetische Sammeln ist differenzierend und auf individuelle Eigenschaften des Gegenstands bezogen. Bei näherer Analyse erweist sich das erste als eine unvollkommene, unvollständige Version des anderen. Dem Sammeln liegt die Tatsache zugrunde, dass der Mensch ein homo videns ist - ein Wesen, das seine höchste Freude in der Betrachtung findet und in dieser Betrachtung für immer verweilen will. Die Darstellung des Entwurfs von Sommer endet mit der Zusammenfassung von konzeptbezogenen kritischen Bemerkungen.

Schlüsselworte: Sammeln, Gegenstand

Information about Author:

WITOLD NOWAK, habilitated doctor, associate professor, Institute of Philosophy, Faculty of Sociology and History, University of Rzeszów; address for correspondence: al. T. Rejtana 16 C, 35-959 Rzeszów, Poland; e-mail: nowwit@interia.pl 